\title{
The Effect of Jatropha curcas $L$ Seed Extract on AST/ALT Activity and The Central Vein Thickness in Liver
}

\author{
Faradila Amirabagya ${ }^{1}$, Rr Ayu Fitri Hapsari ${ }^{2}$, Endah Wulandari ${ }^{3, *}$
}

Faradila Amirabagya', Rr Ayu Fitri Hapsari ${ }^{2}$, Endah Wulandari ${ }^{3, *}$

'Students Faculty of Medicine and Biology Molecular, State IsImic University Syarif Hidayatullah, Jakarta, INDONESIA.

${ }^{2}$ Department of Histology, State Is/mic University Syarif Hidayatullah, Jakarta, INDONESIA.

${ }^{3}$ Department of Biochemistry, State Is/mic University Syarif Hidayatullah, Jakarta, INDONESIA.

\section{Correspondence}

\section{Endah Wulandari}

Department of Biochemistry, State Islmic University Syarif Hidayatullah, JI Kertamukti No 5 Pisangan, Ciputat, 15419, INDONESIA.

Phone no:+062-(021) 744716718

E-mail: endah.wulandari@uinjkt.ac.id

\section{History}

- Submission Date: 20-10-2020:

- Review completed: 12-11-2020;

- Accepted Date: 16-11-2020.

DOI : 10.5530/pj.2021.13.10

Article Available online

http://www.phcogj.com/v13/i1

\section{Copyright}

(c) 2021 Phcogi.Com. This is an open access article distributed under the terms of the Creative Commons Attribution 4.0 International license.

\section{ABSTRACT}

Background: Jatropha is known as anti-inflammatory, antioxidant, anti-fungal, anti-cancer, and has coagulant activity. Jatropha curcas (Jatropha curcas L.) contains toxic compounds such as cursin, ricin and gallic acid. The liver has an important role in the process of metabolism and detoxification of xenobiotic substances. Repeated exposure to toxic compounds can damage hepatic hepatocytes. If the hepatocyte cells are injured, the AST/ALT enzyme is excreted and goes into the blood vessels, as an indicator of liver damage. This is also indicated by changes in the thickness of the central veins. This study aims to determine the effect of giving jatropha seed extract (Jatropha curcas L.) on AST/ALT activity and the central vein thickness in the liver. Materials and Methods: The research design was experimental, using male rats (Rattus novergicus L) Sprague Dawley strain. The rats were given Jatropha seed extract at doses of $0,5,25,50$, and $250 \mathrm{mg} / \mathrm{KgBW}$ for 28 days. To assess liver damage, measurements of AST/ ALT activity and thickness of the central vein in the liver were performed. Results: Jatropha seed extract increased ALT activity at doses of 25.50, and $250 \mathrm{mg} / \mathrm{KgBW}$ compared to the control group $\left(1.207 ; 1.62 ; 1.548 \mathrm{IU} / \mathrm{L} / \mathrm{mg}\right.$ tissue $\left.\times 10^{-3}\right)$; and increased AST activity at doses of $5,25,50$, and $250 \mathrm{mg} / \mathrm{KgBW}$ compared to the control group $(0.769 ; 0.974 ; 1.449 ; 1.185 \mathrm{IU} / \mathrm{L} /$ $\mathrm{mg}$ tissue $\left.\times 10^{-3}\right)$; Central vein thickness increased at doses of 25 and $50 \mathrm{mg} / \mathrm{KgBW}(6.17$ and $4.9 \mu \mathrm{m})$ (Kruskal Wallis; $p>0.05)$. Conclusion: Jatropha curcas L. seed extract increased the activity of AST/ALT and the thickness of the central vein in the liver.

Key words: Jatropha, AST/ALT, The central vein thickness, Liver.

\section{INTRODUCTION}

Jatropha grows in tropical areas such as Indonesia. This plant can grow even though the environmental conditions are little water. Jatropha seeds contain $6.62 \%$ water, $38 \%$ carbohydrates, $38 \%$ fat, and $18 \%$ protein. ${ }^{1}$ Jatropha seeds contain many active compounds that are used as medicines. The active compounds include saponins, flavonoids, tannins, kaempferol, kaempferol-3-rutinoside, nicotiflorine, lipase enzymes, and lipid compounds such as triglycerides, palmitic acid, oleic acid, and linoleic acid. Jatropha is used as anti-inflammatory, antioxidant, anti-fungal, anti-cancer, and coagulant activity. ${ }^{2-5}$ Jatropha seeds are also being developed as an anti-fertilization agent for men. Jatropha seeds cause damage to the seminiferous tubules and decrease the number of spermatozoa.

The liver is the largest gland in humans. The liver has an important role in the body's metabolic processes and as an organ for detoxifying xenobiotic substances. Xenobiotics are chemicals in living things that are not needed by the body and are potentially toxic. Medicines are also an example of xenobiotic substances ${ }^{6,7}$ Likewise jatropha seeds (Jatropha curcas L.) contain toxic compounds such as kursin, ricin, and gallic acid. ${ }^{8,9}$ Repeated exposure to these toxic compounds can damage hepatic hepatocytes, a toxic compound in seeds. Jatropha at a dose of $50 \mathrm{mg} / \mathrm{KgBW}$ can increase LDH activity. ${ }^{10-12}$ Increased LDH activity indicates damage to hepatocyte cells, and previous studies of Jatropha seeds can cause damage to the central vein of mice. ${ }^{13,14}$ Toxic compounds will be carried by blood flow to the liver so that can cause injury to blood vessels. Aspartate aminotransferase (AST and alanine aminotransferase (ALT) are enzymes found mainly in the liver, but also found in red blood cells, heart cells, muscle tissue and other organs, such as the pancreas and kidneys. AST and ALT formerly are called serum glutamic oxaloacetic transaminase (SGOT) and serum glutamic pyruvic transaminase (SGPT), respectively. AST or ALT levels are a valuable aid primarily in the diagnosis of liver disease. This will stimulate the formation of neointima, which is a thickening of the intima of the blood vessels. ${ }^{15,16}$ If the hepatocyte cells are injured (injury cells), the SAST/SALT enzyme will exit the liver cells and enter the blood vessel flow. SAST/SALT can be detected through blood sampling and measurement of AST/ ALT in the liver and can be used as an indicator of liver damage.

Apart from the benefits of jatropha seeds that have been described above, it is necessary to conduct research on the toxicity of jatropha seeds. Until now there has been no research on the toxic effects of jatropha seeds on the liver with the parameters of AST and ALT. AST and ALT examinations are the most common and most commonly performed examinations. The increase in ALT has the highest sensitivity value for assessing liver damage. ${ }^{15}$ Therefore, in this study, the activity of the enzyme 
AST/ALT was measured as a parameter of liver damage and its correlation with the histological picture of the thickness of the central vein of the liver.

\section{METHODS}

\section{Materials}

Materials utilized in the study were as followed: rat of Sprague-Dawley, extract Jatropha curcas L. seed from BALITRO Institution (Bogor), the materials for AST and ALT test of this study using the DiaSys Kit, phosphate buffered saline (PBS) $\mathrm{pH} 7.4$, terraced alcohol, toluene, paraffin, Hematoxylin-Eosin (HE), canada balsam.

\section{Research design}

The research design used was experimental. In this study, the activity of liver AST and ALT was measured and the preparation of liver tissue preparations to measure the thickness of the hepatic central vein. This research was conducted at the Laboratory of the Faculty of Medicine, UIN Syarif Hidayatullah Jakarta. This study used male mice (Rattus novergicus L.) Sprague Dawley strain. The mice are 9-10 weeks old and weigh 250-350 grams. The rats used were in good health. The number of rats was 5 in each of the 5 treatment groups. Treatment doses of Jatropha seed extract: $0,5,25,50$, and $250 \mathrm{mg} / \mathrm{KgWB}$ with removal of resin. The extract was given daily for 28 days.

The rats were terminated using anesthetic method with ether via inhalation. After the mice died, surgery was immediately carried out and the liver organs were removed. The liver is weighed, then some of it is put in a formalin $10 \%$ formalin concentration and Phosphate Buffer Saline (PBS) pH 7,4 solution for making histological preparations and some is stored in a freezer at $80^{\circ} \mathrm{C}$ for the manufacture of homogenate for the ALT/AST test. Homogenate preparation, namely $25 \mathrm{mg}$ of hepatic tissue added with a solution of PBS pH 7.4 then homogenized in a microtube Homogenates were tested for total protein using nanodrops.

\section{AST and ALT measurement}

The AST test of this study using the DiaSys Kit was done in duplicate. The DiaSys kit has two reagents, namely: reagent 1 consisting of TRIS buffer $\mathrm{pH}$ 7.65, L-Aspartate, $\mathrm{MDH}$ (malatdehydrogenase), and LDH (lactate dehydrogenase); and reagent 2 consisting of 2-Oxoglutarate and NADH. $50 \mu \mathrm{l}$ of hepatic tissue homogenate was added to $500 \mu \mathrm{l}$ of reagent 1 into the test tube. Then incubated for 5 minutes at room temperature. Then add $125 \mu \mathrm{l}$ of Reagent 2 then read the absorbance with a spectrophotometer through a wavelength of $340 \mathrm{~nm}$ at 1,2 and 3 minutes. AST activity is calculated based on the formula contained in the kit. In order to determine the level of enzyme purity divided by the total protein of each tissue.

The ALT test in this study used a Duplo DiaSys Kit. The DiaSys kit has two reagents, namely reagent 1 consisting of TRIS buffer $\mathrm{pH} 7.15$, L-Alanine and $\mathrm{LDH}$ (lactate dehydrogenase); and reagent 2 consists of 2-Oxoglutarate and NADH. Hepatic tissue homogenates as much $50 \mu \mathrm{l}$ was added with reagent 1 as much as $500 \mu \mathrm{l}$ into the test tube. Incubate for 5 minutes at room temperature and add $125 \mu \mathrm{l}$ of reagent 2. The absorbance of the solution was read using a spectrophotometer with a wavelength of $340 \mathrm{~nm}$ at 1,2, and 3 minutes. The calculation of AST activity was according to the instructions in the kit. In order to determine the level of enzyme purity divided by the total protein of each tissue.

\section{Preparation of histology slides}

The tissue soaked in formalin is then carried out in the following steps: (1) Dehydration is the process of immersing tissue in an alcohol solution in stages from a concentration of $30 \%, 50 \%, 70 \%, 80 \%, 90 \%$, and absolute alcohol. (2) Clearing is the process of removing and removing alcohol, using a mixture of toluol-alcohol and pure toluol in the ratio of 1:1. (3) Embedding aims to fill the paraffin in the network, namely a mixture of liquid toluol-paraffin with a ratio of 1:1. (4) Blocking is the immersion of tissue in the paraffin to make block preparations so that they can be cut in the embedding casette. (5) The hardened paraffin block can then be cut using a rotary microtome. (6) The resulting preparations were stained with Hematoxicillin-Eosin. The distribution data was not normal and homogeneous, so the Kruskal-Wallis test statistic was performed. Histological preparations were observed and measured the thickness of each central vein in the preparation using a binocular microscope with a magnification of 20X. Each preparation counted 5 visual field areas and averaged the thickness of the central veins found.

\section{RESULTS}

\section{ALT and AST activity}

The results of measuring the activity of ALT that have been given Jatropha seed extract in mice with control doses, 5, 25, 50 and $250 \mathrm{mg}$ / KgBW can be seen in Figure 1. The lowest ALT activity was in the 5 $\mathrm{mg} / \mathrm{KgBW}$ dose group and the highest activity was in the $50 \mathrm{mg} / \mathrm{KgBW}$ dose then a dose of $250 \mathrm{mg} / \mathrm{KgBW}$ (Kruskal-Wallis; $\mathrm{p}>0,05$ ). The results of the measurement of the average AST activity of the hepatic tissue that had been given Jatropha seed extract in mice with control doses, 5 , 25,50 , and $250 \mathrm{mg} / \mathrm{KgBW}$ (Kruskal-Wallis; $\mathrm{p}>0,05$ ). The results of the measurement of the AST test, there was a decrease in AST activity at a dose of $250 \mathrm{mg} / \mathrm{KgBW}$ compared to a dose of $50 \mathrm{mg} / \mathrm{KgBW}$. Measuring the AST/ALT ratio, the control dose group showed the lowest AST/ALT ratio. The highest AST/ALT ratio is at a dose of $50 \mathrm{mg} / \mathrm{KgBW}$ (KruskalWallis; $\mathrm{p}>0,05)$ (Figure 1).

\section{The thickness of the central vein liver}

In this study, a quantitative assessment of the central vein was carried out. The quantitative assessment is by measuring the thickness of the central vein. Measurement of the thickness of the central vein using a microscope with a magnification of 20x (Figures 2 and 3). In measuring the thickness of the hepatic central vein, the group dose of $5 \mathrm{mg} / \mathrm{KgBW}$ showed the lowest thickness. Meanwhile, the $25 \mathrm{mg} / \mathrm{KgBW}$ dose group had the highest thickness followed by the $50 \mathrm{mg} / \mathrm{KgBW}$ dose.

\section{DISCUSSION/CONCLUSION}

\section{ALT and AST activity}

In this study, the activity of ALT was higher than that of AST. This is due to the influence of the location of the two enzymes. The ALT enzyme is in the cytosol while the AST enzyme is only $20 \%$ in the cytosol and $80 \%$ is in the mitochondria. ${ }^{31}$ For this reason, the ALT enzyme is better

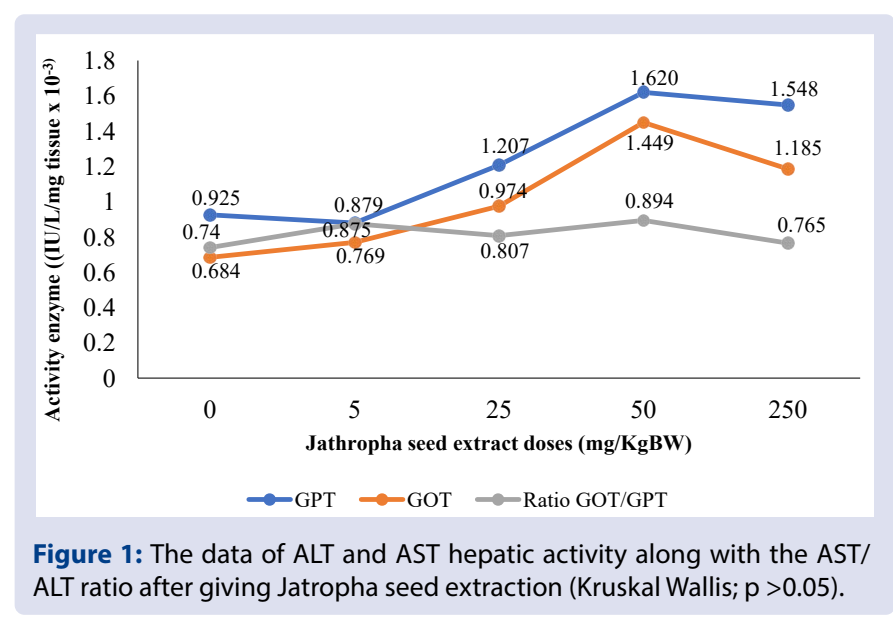



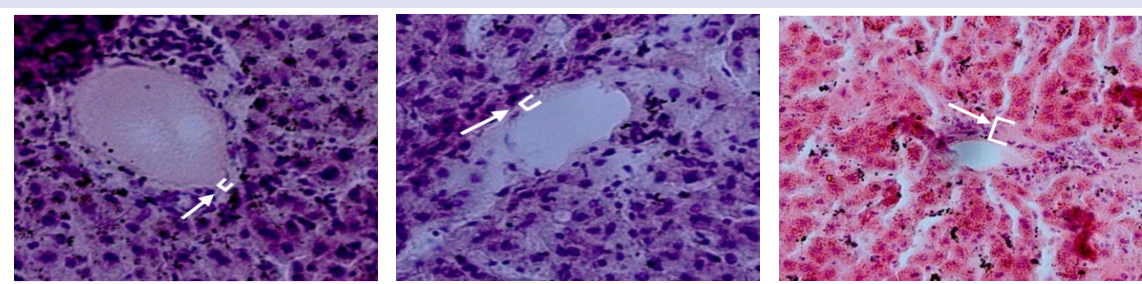

A

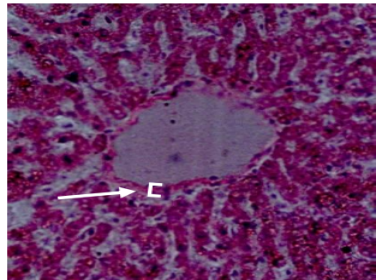

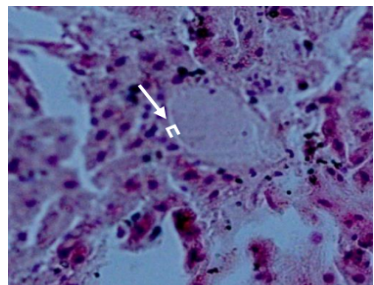

E

Figure 2: The Liver Central Vein Thickness at 20x magnification. Jatropha seed extract with a dose: (A) 0 (control) (B) $5 \mathrm{mg} / \mathrm{KgBW}$ (C) $25 \mathrm{mg} / \mathrm{KgBW}$ (D) $50 \mathrm{mg} / \mathrm{KgBW}$ (E) $250 \mathrm{mg} / \mathrm{KgBW}$. The arrows indicate the diameter of the hepatic central vein.



Figure 3: Data on the average thickness of the rat liver central vein after giving jatropha seed extract (Kruskal Wallis; $p>0,05$ ).

at assessing liver damage. There was a decrease in ALT activity at a dose of $5 \mathrm{mg} / \mathrm{KgBW}$ compared to the control dose. This study only ALT decreased at a dose of $5 \mathrm{mg} / \mathrm{KgBW}$. This could be due to a toxic factor that may be present in the $1 \% \mathrm{Na}$-CMC substance used in the study and is associated with a lower half-life of ALT compared to that of AST. At doses $250 \mathrm{mg} / \mathrm{KgBW}$ decreased both AST and ALT activity compared to the $50 \mathrm{mg} / \mathrm{KgBW}$ dose. This is because at a dose of 250 $\mathrm{mg} / \mathrm{KgBW}$, ricin has been removed from jatropha seeds. The dose of 50 $\mathrm{mg} / \mathrm{KgBW}$ shows that the toxic substances contained in Jatropha seeds can make the cell condition become hypoxic. Large toxic substances can damage hepatocyte cell membranes, thereby increasing membrane permeability. When a cell leak occurs, the enzymes contained in the hepatocytes will experience changes in activity. This can increase the activity of ALT and AST.

Risin is the main toxic substance contained in Jatropha seeds. At a dose of $50 \mathrm{mg} / \mathrm{KgBW}$, the content of ricin is higher so that at a dose of $250 \mathrm{mg} / \mathrm{KgBW}$ there is a decrease in AST and ALT activity. Risin is a protein that is widely found in plants. Risin belongs to the RIPs (Ribosome Inactivating Proteins) group. RIPs are toxic enzymes that can cause tissue inflammation and eventually cause tissue damage. The toxic substance ricin destroys the 28s rRNA present in the ribosomes. Damaged 28s rRNA will inactivate the peptidyltransferase enzyme activity. This will cause cellular stress, especially on the ribosomes. Toxins such as ricin will increase the phosphorylation of cytoplasmic membrane receptors and EGFR (Epidermal Growth Factor Receptor). Increased phosphorylation will activate protein kinase B (PKB/Akt1) and downregulate ERK (Extracellular Signal-Regulated Kinase). Decreased kinase regulation will inactivate ribosomes due to the presence of pro-inflammatory cytokines produced by the toxic substance ricin. Inactivation of ribosomes will increase transcription regulators such as CHOP (Enhancer binding protein Homologous Protein) and produce byproducts in the form of more massive pro-inflammatory cytokines. In addition, ricin-induced ribosome inactivation stimulates MAP kinase. MAP kinase will stimulate TACE (TNF Alfa Converting Enzyme) and ADAM17 which will further create cellular stress and interfere with the translation process of ribosomes and mitochondria. ${ }^{18}$ The body will carry out the process of homeostasis when there is cellular damage and interference with the translation process by producing growth factors. The growth factor will stimulate the c-Myc cascade signal and the CDKs, E2F1, and cyclin signal pathways. These pathways will stimulate 
cell proliferation. In addition, the translational dysfunction of RNA will stimulate $\mathrm{PI} 3 \mathrm{~K} \delta$ activation. $\mathrm{PI} 3 \mathrm{~K} \delta$ activation will activate other pathways such as the Akt and mTOR lines. This will improve the E2F1 translation. The results of E2F1 synthesis will induce the process of cell biogenesis and proliferation. ${ }^{19}$ With cell proliferation, it can increase the process of cell protein (enzyme) synthesis.

The toxin ricin is the most toxic compound derived from plants. Ricin toxin is included in the glycoprotein compound and consists of two chain compounds, namely the $\mathrm{A}$ chain and the $\mathrm{B}$ chain. The ricin toxin can accumulate and damage various cells, especially in the liver and spleen cells. Risin toxin will bind to mannose receptors on the cell membrane. In addition, ricin toxin can bind to cell glycoprotein membranes via terminal galactose receptors. After binding to specific receptors, the toxin ricin enters cells by endocytosis by means of clathrin-dependent or clathrin-independent pathways. Then, the toxin ricin goes to the endosome of the golgi body and the endoplasmic reticulum. In cells, there is a cytosolic protease enzyme which functions to degrade toxic substances, including the toxin ricin. However, the toxin ricin will enter the membrane of the endoplasmic reticulum. This causes the inactivation of the cytosolic protease enzyme so that the ricin toxin is not degraded by cells. Mannose receptors are abundant in liver cells so that they can increase toxicity to the liver and cause cellular damage. Cellular damage to the liver will produce additional compounds in the form of free radicals and the production of more proinflammatory cytokines..$^{18}$ It was stated that in experimental animal mice, they will experience cellular damage to Kupffer cells, damage to liver cells, and thrombus to the hepatic vascular within 4 hours. ${ }^{20}$

This damage will trigger the release of pro-inflammatory cytokines. The amount of proinflammatory cytokines such as TNF alpha and IL-6 that are produced depends on the extent of the liver damage. TNF alpha and IL-6 residing in Kupffer cells are induced by LPS, the c5a complement system and by activation of ICAM-1 leukocytes. TNF alpha will further increase the expression of 1L-6 through TNFR 1 activation. IL- 6 is widely produced in Kupffer cells and is regulated by the MyD88 pathway. IL- 6 will bind to its specific receptor, namely the IL- 6 receptor on the cell membrane of hepatocytes. The binding of IL- 6 to its specific receptor will activate the STAT-3 pathway and increase the production of SOC 3. Furthermore, STAT-3 will induce hepatocyte proliferation. When there is damage, the liver will regenerate cells through the resulting growth factors. ${ }^{21}$ The expression of the EFG (Epidermal Growth Factor) growth factor ligand increases in damaged hepatocytes. EFG in hepatocytes is activated autocrine with the help of amphiregulin and TGF alpha. EGF activation stimulates hepatocyte proliferation and supports hepatocyte growth after injury. The growth factor FGF (Fibroblast Growth Factor) will also be stimulated after cellular injury to the liver. FGF is activated via its specific receptor, namely the transmembrane tyrosine kinase receptor. In addition, hepatocytes express Wnt protein. Wnt protein functions as a growth factor and cell differentiation factor. The Wnt pathway will stabilize the translocation of beta catenin nuclear transfer and stimulate DNA synthesis to support hepatic cell proliferation. Other growth factors that play a role are VEGF (Vascular Endothelial Growth Factor), PDGF (Platelet Derived Growth Factor), BMP (Bone Morphogenetic Protein), and TGF (Transforming Growth Factor). Binding of FGF with FGFR, EGF with EGFR, PDGF and VEGF with PDGFR will activate the phosphorylation cascade and recruit the protein adapter Grb2 and nucleotide exchage factor SOS.22 Furthermore, it will activate PI3K (Primarily Phosphoinositide-3 kinase)-Akt, protein kinase B and Erk Mitogen-activated protein kinase (MAPK). The phosphorylated ERK will enter the nucleus and activate transcription genes such as c-myc or Rsk receptors which will activate cell proliferation genes. BMP-2 activates the cell proliferation pathway via the MAPK Erk pathway. TGF beta is a potent factor in cell proliferation. TGF beta stimulates cell proliferation through the Smad
2, Smad 3, and Smad 4 activation pathways. Wnt protein will bind to Frizzled receptors and stimulate beta catenin influx. B catenin will activate the cyclin D1 and c-myc cell protein cycle. All of these things stimulate hepatocyte cell proliferation. ${ }^{21}$

Jatropha seeds contain toxic compounds, namely ricin compounds which can cause hepatic cellular damage. The liver organ is an organ that can undergo cellular regeneration when there is exposure to toxic substances. This is due to its main function in detoxifying toxic substances. The regenerated liver cells had a higher aspartate aminotransferase enzyme value than normal liver tissue. This research sample using hepatic tissue and homogensized. Furthermore, measurements are carried out using the Schneider and Hogeboom method. In regenerating liver, the activity of aspartate aminotrasnferase shows $3,180+/-220$ while in normal liver tissue the activity is only $2,680+/-180$.This is in line with this study which shows that in the liver regeneration process there is an increase in the aminotrasnferase enzyme. In this study, it was shown that the proliferating liver cells can increase the number of mitochondria cells both physically and chemically compared to normal liver cells. In the cell, the aminotransferase enzyme will undergo various competitive reactions and will then enter the pyrimidine synthesis process. In entering pyrimidine synthesis, the enzyme aminotransferase is influenced by factors present in the cell. The enzymatic reaction of aminotrasnferase is reversible depending on the concentration of the reactants. Cells generally experience an increase in the activity of the aminotransferase enzyme. The most important factor in enzyme flow is not determined by the concentration of the aminotransferase enzyme, but by the competition of the aminotransferase enzyme in various other reactions.

In this study, the results of the ratio between sewer and ALT were less than 1 in all treatment groups. The results showed that the rat's liver did not experience massive necrosis. The DeRitis ratio theory states that the AST/ALT enzyme ratio can be a diagnostic tool for assessing liver damage. The DeRitis ratio is divided into 2 categories, namely the type of inflammation (AST/ALT $\leq 1)$ and the type of necrosis (AST $>$ ALT $\geq$ 1 ). The severity and type of cell damage (inflammation or necrosis) is influenced by the location of the enzymes AST and ALT. The location of the damage in the cytoplasm or damage in the mitochondria will affect the ratio of the enzyme AST / ALT. In liver damage, ALT activity will exceed AST activity. Only when there is massive necrosis, that is, when mitochondrial damage occurs, does AST activity exceed ALT activity. The more necrosis of hepatocytes, the more severe the damage will be. The ratio of AST> ALT will increase in conditions of chronic liver damage such as in hepatitis C. In hepatitis C, there is an increase in the AST/ALT ratio $>1$ because the liver cells undergo fibrosis and develop into cell cirrhosis. In the case of fatty liver due to alcohol, the ratio of AST/ALT can be> 2. This is because alcohol undergoes metabolic processes in the mitochondria. The by-product in the form of ROS will be generated from alcohol metabolism. ROS will damage the mitochondria so that it interferes with AST activity. The AST/ALT ratio can be $(>4)$ if the liver has more massive liver damage such as in fulminant hepatitis. In other words, the AST/ALT ratio can be used in determining the differential diagnosis of liver cases. In this study, the AST/ALT ratio of all treatments $<1$ indicates that the type of liver damage is the type of inflammation, not the type of necrosis. So that AST activity is lower than ALT activity. ${ }^{20}$ In acute conditions, ALT activity tends to increase more than ALT activity. This clinical condition occurs in humans. However, this also represents the condition of the mice. In the last 30 years, rats are the most widely used animal for experimental research. Research shows that the physiological conditions of mice can represent the condition of the human body. Rats also have genetic, biological, and characteristic attitudes that are very similar to humans. There are currently more than 1 million published journals that use mice. So that physiological theories such as the AST/ALT ratio in humans can also be applied to the condition of mice. ${ }^{21}$ 


\section{The thickness of the central vein liver}

The increase in AST and ALT activity from control doses to high doses. This is because the cellular injury caused can stimulate the production of intracellular enzymes. However, at very high doses there was a decrease in AST and ALT activity. The decrease in AST and ALT activity is due to the presence of flavonoids as antioxidants. Flavonoids are good reducing compounds that can prevent oxidation reactions by free radicals. ${ }^{23}$ Flavonoids will bind to specific receptors, namely ER beta receptors on the surface of cell membranes. The bond between flavonoids and ER beta receptors will activate the intracellular kinase cascade reaction and produce eNOS (endothelial Nitric Oxide Synthase) and NO (Nitric Oxide). High levels of NO will change the cysteine in the Keap-1 protein (Kelch ECH Associating Protein) and produce the transcription factor Nrf2 (Nuclear factor-erythroid-2 Related Factor 2) to the cell nucleus. Nrf2 will then bind to the ARE (Antioxidant Response Element) receptor. ARE receptors are on the promoter of genes that produce antioxidant enzymes so that they will increase the production of the enzymes superoxide dismutase, glutathione, and NADPH Quinine Oxireductase. ${ }^{22}$

The increase in blood vessel thickness is one of the body's responses to vascular injury. When vascular injury occurs, the vascular wall will secrete proinflammatory mediators, growth factors, and will increase the expression of HMGB (High-Mobility Group Box). HMGB2 plays a role in regulating DNA transcription, replication, and tissue repair. HMGB2 will bind to the RAGE receptor (Receptor of Advanced Glycation End Products). The bond between HMGB2 and the RAGE receptor activates phosphorylation of p47phox. Phosphorylation of $\mathrm{p} 47 \mathrm{phox}$ will produce a by-product in the form of ROS. The production of ROS will increase along with the increased production of NADPH oxidase when vascular injury occurs. ROS will activate the p42/44 MAPK (Mitogen-activated Protein Kinase) pathway, p38MAPK, and the Akt pathway. This pathway increases the expression of collagen type 1 alpha 1 (Colla1), collagen type 3 alpha 1 (Col3a1), MMP-2 (Matrix Metalloproteinase-2), and MMP-9 thereby stimulating smooth muscle cell migration and proliferation to form the neointima layer. In this study, the dose of $5 \mathrm{mg} / \mathrm{KgBW}$ had the lowest thickness compared to other doses. This is because the levels of toxicity in Jatropha seeds at a dose of $5 \mathrm{mg} / \mathrm{KgBW}$ are still low, so the increase in HMGB2 expression is also low. At a dose of $50 \mathrm{mg} / \mathrm{KgBW}$ has the highest levels of ricin. The highest levels of toxic substances will increase the expression of HMGB2 and stimulate the formation of massive neointima. With the massive growth of neointima, the body will activate the PDZK1 gene. The PDZK1 gene will suppress the BCR (Breakpoint Cluster Region) kinase located in vascular smooth muscle cells. Suppression from BCR will reduce the formation of neointima. ${ }^{24}$ So that at a dose of $50 \mathrm{mg} /$ $\mathrm{KgBW}$ there is a decrease in the thickness of the central veins compared to the dose of $25 \mathrm{mg} / \mathrm{KgBW}$. The thickness of the central vein at a dose of $25 \mathrm{mg} / \mathrm{KgBW}$ had the highest thickness. This is because the levels of toxic substances increase HMGB2 expression but have not been able to stimulate the PDZK1 gene so that the suppression of neointima formation has not occurred at a dose of $25 \mathrm{mg} / \mathrm{KgBW}$. The effect of Jatropha seeds increases the highest VEGF levels at a dose of $25 \mathrm{mg} /$ KgBW. This is because the increase in the formation of neointima is directly proportional to the increase in the production of growth factors. ${ }^{13,21}$ At a dose of $250 \mathrm{mg} / \mathrm{KgBW}$ there is a decrease in the thickness of the central vein. This is because at a dose of $250 \mathrm{mg} / \mathrm{KgBW}$ it has the effect of high antioxidant levels so that it can suppress the ROS activity and the signal transduction pathways that play a role. The antioxidants contained are flavonoids. Flavonoids can inhibit the ratio of neointima/ media and PCNA (Proliferating Cell Nuclear Antigen) significantly. This is because flavonoids can suppress the signal transduction of Akt/ glycogen synthase kinase, ERK (Extracellular Signal-Regulated Kinase), and the STAT-3 (Signal Transducers and Activators of Transcription 3) pathway, very few central veins were obtained. ${ }^{24}$ This can affect the results of the study. In addition, the obstacle that was obtained was the high thickness of the central vein in the control group. For this reason, further research is needed regarding the toxicity levels of $\mathrm{Na}-\mathrm{CMC}$ used.

\section{ACKNOWLEDGEMENT}

The authors acknowledge the financial support of this study by The State Islamic University Syarif Hidyatullah by "Development of Science research grants"

\section{CONFLICTS OF INTEREST}

\section{None.}

\section{REFERENCES}

1. Oskoueian E, Abdullah N, Ahmad S, Saad WZ, Omar AR, Ho YW. Bioactive Compounds and Biological Activities of Jatropha curcas $L$ Kernel Meal Extract. Int J Mol Sci. 2011;12(9):5955-70.

2. Balaji R, Rekha N, Deecaraman M, Manikandan L. Antimetastatic and antiproliferative activity of methanolic fraction of Jatropha curcas against B16F10 melanoma induced lung metastasis in C57BL/6 mice. Afr J Pharm Pharmacol. 2009:3(11):547-55

3. Aregheore, E.M. Becker, K Makkar HPS. Detoxification of a toxic variety of Jatropha Curcas using heat and chemical treatments, and preliminary nutritional evaluation with rats. Institute for Animal Production in the Tropics and Subtropics. University of Hohenheim, Germany; 2003.

4. Sharma AK, Gangwar M, Kumar D, Nath G, Sinha ASK, Tripathi YB. Phytochemical characterization, antimicrobial activity and reducing potential of seed oil, machine oil and oresscake of Jatrhropha curcas. Avicenna J Phytomed. 2016;6(4):366-75.

5. Tolera, Amenu. The Effects of Ricinus Communis And Jatropha Curcas Seed Aqueous Extracts on The Histology of Uterus and Ovary in Mice. India: Addis Ababa University. 2004

6. Patel D, Sen DJ. Xenobiotics: An Essesntial Precursor for Living System". India: Department of Pharmaceutical Chemistry Shri Sarvajanik Pharmacy College. 2013.

7. Sozmen M, Devrim AK, Tunca R, Bayezit M, Dag S, Essiz D. Protective ef fect of silymarin on fumonisin B-I induced hepatotoxicity in mice. J Vet Sci. 2014; 15(1):51-60

8. Worbs S, Kohler K, Pauly D, Avondet MA, Schaer M, Dorner MB and Dorner BG. Recinus communis intokxications in human and veterinary medicine-A Summary of Real Cases. Toxins. 2011;3(10):1332-72.

9. Tolera, Amenu. The Effects of Ricinus Communis And Jatropha Curcas Seed Aqueous Extracts on The Histology of Uterus and Ovary in Mice. India: Addis Ababa University. 2004.

10. Chaudhary A, Chauhan V. Lactate dehydrogenase as an indicator of hepar diseases. J Adv Med Dent Sci Res. 2015;3(5):S20-22.

11. Elustondo P.A., White A.E., Hughes M.E., Brebner K. Pavlov E. and Kane D.A. Physical and functional association of lactate dehydrogenase (LDH) with skeletal muscle mitochondria. J Bio Chem. 2013;288(35):25309-17.

12. Koukourakis MI, Giartromanolaki A, Sivvidis E, Bougiokas G, Didilis V, Gatter $\mathrm{KC}$. Harris AL. Lactate dehydrogenase-5 (LDH-5) overexpression in non-smallcell lung cancer tissues is linked to tumour hypoxia, angiogenic factor production and poor prognosis. BJ Cancer. 2003;89:877-85.

13. Fontana RJ. Acute hepar failure including acetaminophen overdose. Med Clin North Am. 2008;92(4):761-94.

14. Ferrara N, Gerber HP, LeCouter J. The biology of VEGF and its receptors. Nat Med. 2003;9(6):669-76

15. Huang XJ, Choi YK, Im HS, Yarimaga O, Yoon E, Kim HS. Aspartate aminotransferase (AST/GOT) and alanine aminotransferase (ALT/GPT) detection techniques. Sensora (Basel). 2006;6(7):756-82.

16. Ohno H., Shirato K., Sakurai T., Ogasawara J., and Sumitani Y. Effect of exercise on HIF-1 and VEGF signaling. JPFSM. 2012;1(1):5-16

17. Sookoian S, Pirola CJ. Liver Enzymes, Metabolomics and Genome-Wide Association Studies: From Systems Biology to the Personalized Medicine. World J Gastroenterology. 2015;21(3):711-25

18. Moon Y. Ribosomal Alteration-Derived Signals for Cytokine Induction in Mucosal and Systemic Inflammation: Noncanonical Pathways by Ribosomal Inactivation. Mediators Inflammation. 2014;14:1-11.

19. Gnanasundram SV dan Fahraeus R. Translation Stress Regulates Ribosome Synthesis and Cell Proliferation. Int J Mol Sci. 2018;19(12):3757.

20. Kuntz E, Kuntz HD. Hepatology: Textbook and Atlas. 3rd Edition. Germany: Springer Medizin Verlag. 2008 
21. Zhang SM, Zhu LH, Zhang Y. Interferon Regulatory Factor 9 is Critical for Neointima Formation Following Vascular Injury. 2014.

22. Leonardo CC, Dore S. Dietary Flavonoids Are Neuroprotective Through Nrf2coordinated Induction of Endogenous Cytoprotective Proteins. Nutr Neurosci. 2011;14(5):226-36.
23. El-Baz FK, Aly HF, Abd-Alla HI, Saad SI. Bioactive Flavonoid Glycosides and Antidiabetic Activity of Jatropha curcas on Streptozotocin-Induces Antidiabetic Rats. Int J.Pharrm Sci Rev Res. 2014;29(2)26:143-56.

24. Lee RW, Sachardou A, Kelly EB, Oltmann SC, Zhu W, Ahmed M, et al. PDZK1 Prevents Neointima Formation via Suppression of Breakpoint Cluster Region Kinase in Vascular Smooth Muscle. Journal PloS ONE. 2015:1-16.

\section{GRAPHICAL ABSTRACT}

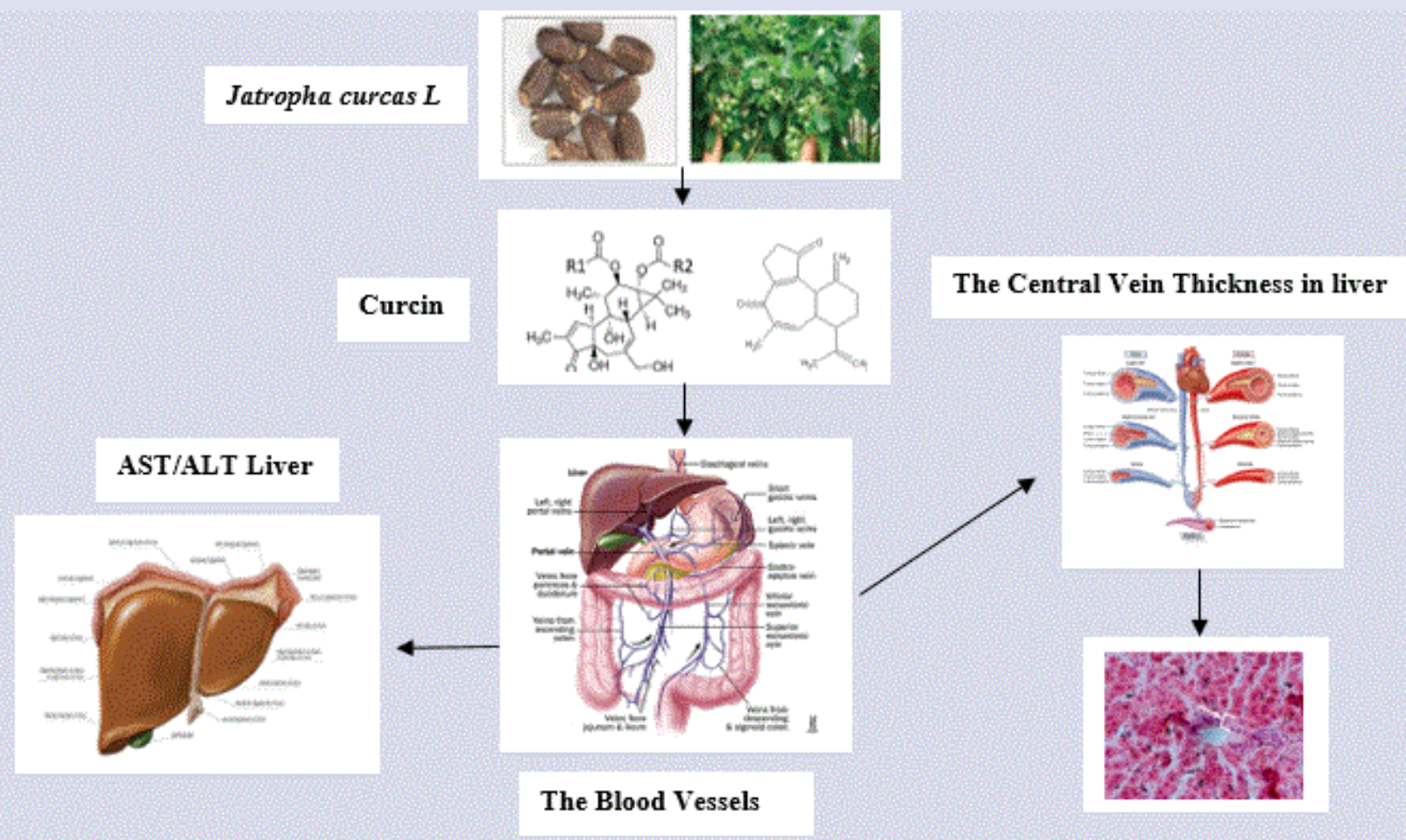

\section{SUMMARY}

- Jatropha is known as anti-inflammatory, antioxidant, anti-fungal, anti-cancer, and has coagulant activity.

- Jatropha curcas (Jatropha curcas L) contains toxic compounds such as curcin, ricin and gallic acid.

- The liver has an important role in the process of metabolism and detoxification of xenobiotic substances.

- Repeated exposure to toxic compounds can damage hepatic hepatocytes.

- If the hepatocyte cells are injured, the AST/ALT enzyme is excreted and goes into the blood vessels, as an indicator of liver damage.

- Jatropha curcas L. seed extract increased the activity of AST/ALT and the thickness of the central vein in the liver.

\section{ABOUT AUTHORS}

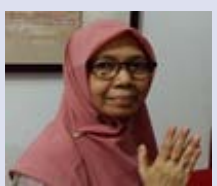

Endah Wulandari PhD is an Assistant Professor at the Department of Biochemistry, Faculty of Medicine, State IsImic University Syarif Hidayatullah, Jakarta, Indonesia. She has projects in collaboration with national institutions. Has experience in the area of Biochemistry, with emphasis on Metabolism, Hypoxia, Herbs, Protein and Genome.

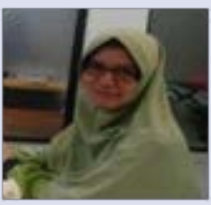

Rr Ayu Fitri Hapsari, M.Sc is a lecturer in Faculty of Medicine, State IsImic University Syarif Hidayatullah, Jakarta, Indonesia. The Areas of concentration related to organ tissue. She is head of Histology Department. 


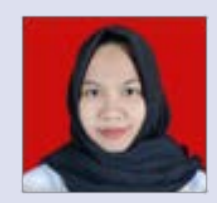

Faradila Amirabagya is Students of Faculty of Medicine, State IsImic University Syarif Hidayatullah, Jakarta, Indonesia.

Cite this article: Amirabagya F, Hapsari RAF, Wulandari E. The Effect of Jatropha curcas L Seed Extract on AST/ALT Activity and The Central Vein Thickness in Liver. Pharmacog J. 2021;13(1): 66-72. 